\title{
Oreos Versus Orangutans: The Need for Sustainability Transformations and Nonhierarchical Polycentric Governance in the Global Palm Oil Industry
}

\author{
Gabriel B. Snashall *(D) and Helen M. Poulos (D) \\ College of the Environment, Wesleyan University, Middletown, CT 06457, USA; hpoulos@wesleyan.edu \\ * Correspondence: gsnashall@wesleyan.edu
}

check for updates

Citation: Snashall, G.B.; Poulos, H.M. Oreos Versus Orangutans: The Need for Sustainability Transformations and Nonhierarchical Polycentric Governance in the Global Palm Oil Industry. Forests 2021, 12, 252. https://doi.org/10.3390/f12020252

Academic Editor: Luis Diaz-Balteiro

Received: 25 January 2021

Accepted: 14 February 2021

Published: 22 February 2021

Publisher's Note: MDPI stays neutral with regard to jurisdictional claims in published maps and institutional affiliations.

Copyright: (C) 2021 by the authors. Licensee MDPI, Basel, Switzerland. This article is an open access article distributed under the terms and conditions of the Creative Commons Attribution (CC BY) license (https:/ / creativecommons.org/licenses/by/ $4.0 /)$.

\begin{abstract}
While the myriad benefits of palm oil as a food, makeup, and cleaning product additive drive its demand, globally, the palm oil industry remains largely unsustainable and unregulated. The negative externalities of palm oil production are diverse and devastating to tropical ecosystem integrity and human livelihoods in palm oil nations. Given the current trend in increasing sustainability and transparency in global supply chains, we suggest that sustainability policy reforms are feasible and have the potential to promote 21st century U.S. and international sustainability standards. Polycentric governance may improve the attainment of sustainable global palm oil standards with a set of rules that interact across linear and nonlinear hierarchies and structures, thereby improving collaboration efforts, and increasing connectivity and learning across scales and cultures. Transformations towards sustainability in international palm oil governance has the potential to make valuable contributions to global sustainable development and improve the prosperity of poor rural communities in the tropics by providing a framework for achieving palm oil trade transparency and aligning the sustainability goals across a range of actors.
\end{abstract}

Keywords: palm oil; transparency; polycentric governance; roundtable on sustainable palm oil; sustainability; global supply chains; transformation

\section{Introduction}

Palm oil is embedded in myriad food products that fill pantries and cupboards around the world [1]. Due to its shelf-stable nature, palm oil is often a key ingredient in inexpensive snack foods. From chocolate ice cream to crackers, cakes, and cleaning supplies, this oil saturates a wide range of processed foods and consumer goods [2]. However, palm oil does more than just settle a sugary craving for delightful confectionery-it drives global demand for makeup and cosmetics, cleans our clothes and our homes, provides biofuel to the world, and livable wages for poor rural communities across the tropics [3-5]. As an ingredient in most toothpaste and shampoo products, palm oil has also become an integral part of our hygienic routine [6,7]. The oil's aroma profile and sensory property makes it a popular ingredient in skin moisturizers, perfumes, lipsticks, and fingernail polish [8,9]. Meanwhile, corporations also manipulate the oil's chemical properties for internal combustion engines, and as additives for producing some of the cheapest detergents and cleaning products on the market $[10,11]$.

While the benefits of palm oil as fuel, food, makeup, and cleaning product additives drive its demand, globally, palm oil production remains unsustainable and unregulated [12-14]. Scientists and governments around the world have failed to inform consumers of the external costs of a snack-filled cupboard or a well-provisioned washroom, nor are most consumers aware of the externalities of palm oil production $[15,16]$.

Recent palm oil industry growth is massive, mostly because palm oil offers the cheapest shelf-stable vegetable oil option, while requiring the smallest land area for cultivation, relative to other plant-based oils [17-19]. Estimates suggest the compounded annual 
growth rate of the palm oil industry lies between 3-4.5\% [20]. At the high end of this range, future palm oil industry growth is projected to increase at a staggering $5.6 \%$ peryear through 2030, exceeding all past industry projections [21-23]. On the one hand, poverty-stricken farmers in poor rural communities benefit from growing the oil crop and improving their quality of life through income [17]. On the other hand, the oil's production exacerbates social and environmental problems in emergent nations and flattens health and economic growth curves of poor communities $[13,24,25]$.

The purpose of this review is to reveal the magnitude of palm oil environmental impacts on people and planet, and to offer a framework for sustainable palm oil regulation. We begin with a synthesis of the externalities of palm oil production, tracing the journey of palm oil snacks from the palm oil plantation to the cupboard. Aggregating data from a range of primary sources, we then provide a map for tracing the impacts of palm oil pantry products on tropical forest integrity. Finally, we offer a framework for transforming the palm oil industry through polycentric governance and global coordination.

\section{Externalities of Palm Oil Production}

The negative externalities of the palm oil industry are diverse and devastating to tropical ecosystem integrity, as the global market for cheap vegetable oil and biodiesel alternatives negate tropical conservation efforts [26-28] (Figure 1). Debt bondage, forced labor, child labor, and human trafficking are just some of the social costs borne by citizens of palm oil nations such as Indonesia, Malaysia, Ecuador, Guatemala, and Brazil [29,30]. On top of these social costs are the large-scale environmental hazards embedded in the palm oil production process [31], including increased wildfire activity, deforestation, biodiversity loss, and increased $\mathrm{CO}_{2}$ emissions from forest conversion to monoculture plantations [32,33].

In 2019 alone, Indonesia, Malaysia, and Singapore imported $57.8 \%$ and $38.5 \%$ of the U.S. palm oil share, respectively [20]. Ecuador, Guatemala, Ghana, Colombia, and Brazil hold less than 1\% of the global palm oil market currently, but the recent increase in licensing private entities to overexploit ecosystem resources for short-term economic gain, and ignoring the discount rate in calculating environmental goods, has led to tropical resource overexploitation and ecosystem degradation by such land-use policies [34,35].

A comparison of the external costs of oil production across palm oil export nations versus the total costs of American palm oil imports is revealing. Incorporating oil production costs from forests lost to wildfires, deforestation, land-use, or land-cover change from palm oil cultivation provides a stark picture of the real costs of American reliance on the palm oil industry. Satellite imagery corroborates empirical forest loss for industrial monocrop creation but also shows that the nonforest land capture and forest losses from new plantation establishment are viable threats to tropical system integrity [36-38]. Furthermore, palm oil industry expansion strategically accrues different types of land, both official and unofficial, indigenous and emigrant, for the exclusive use of land for oil production [39,40].

An accurate forest loss measurement of plantations should, therefore, consider the amount of land cleared for plantation creation and the opportunity costs associated with land stored for future plantations, meaning land withheld from conservation actors and institutions who would otherwise recover any impaired, damaged, or destroyed land. It should also include any forest loss due to social conflict and economic disruption, such as in cases where indigenous communities are forced to substitute sustainable community-based agriculture for unsustainable slash-and-burn cultivation, in competing for food access and security amid the rapid expansion of monocrop plantations [41,42]. 


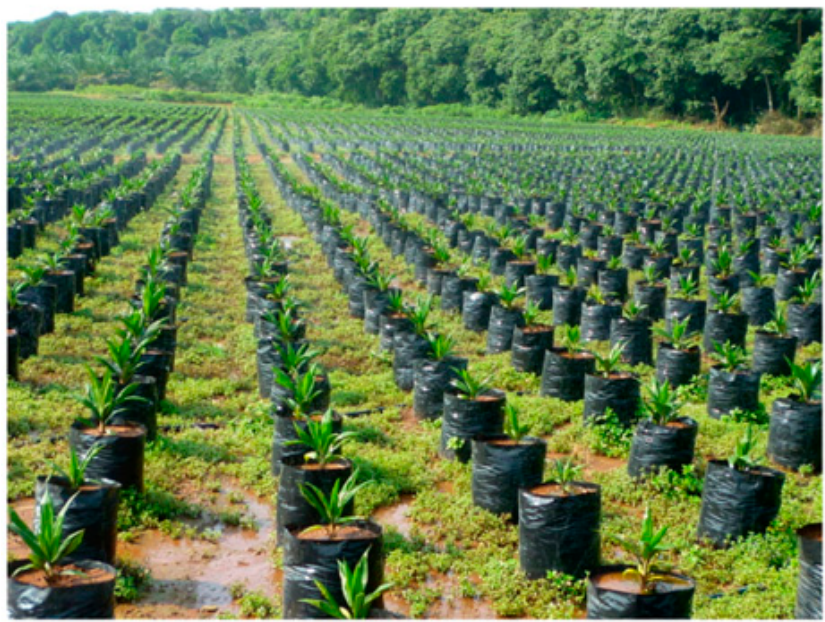

(A)

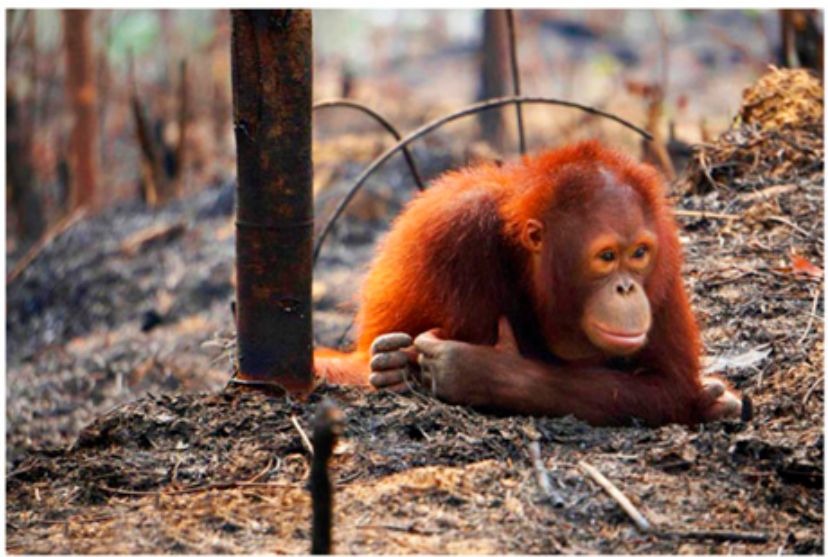

(C)

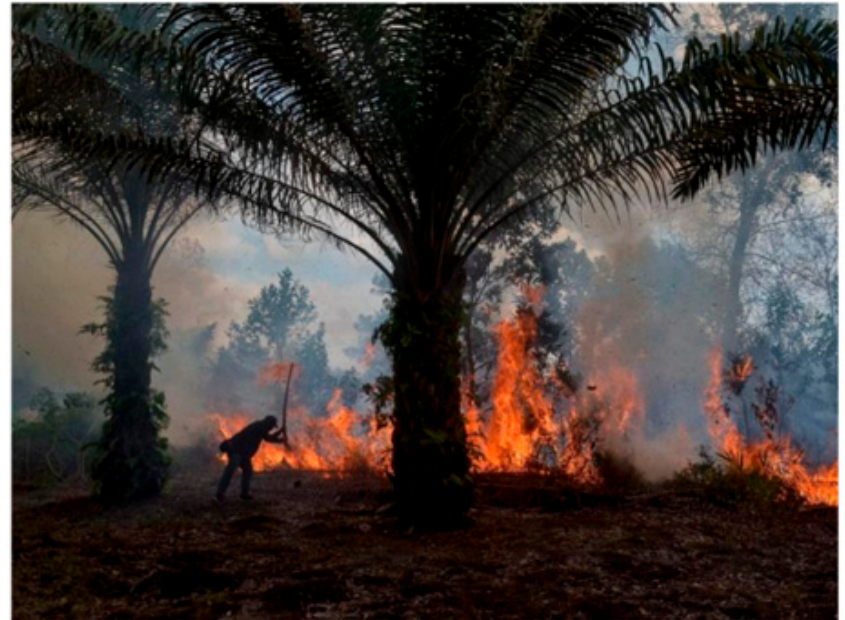

(B)

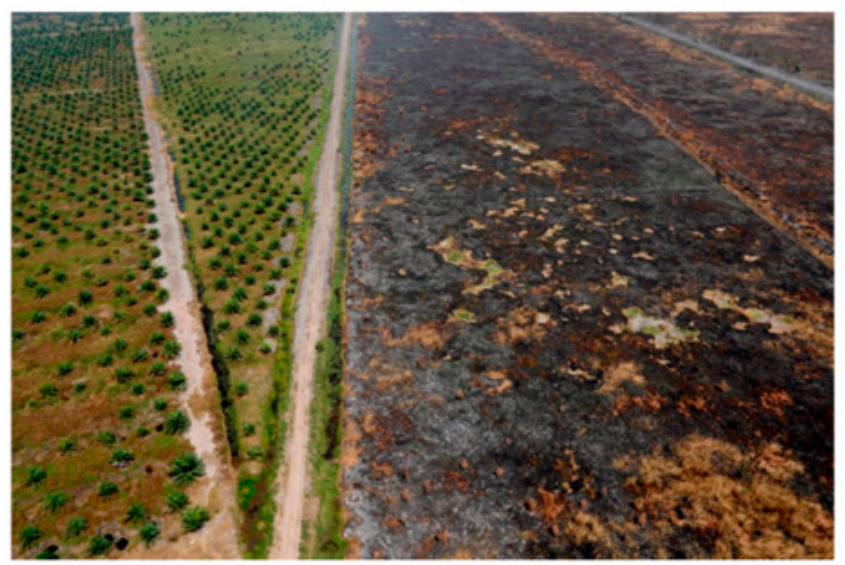

(D)

Figure 1. Monocrop plantations, owned and operated by transnational corporations, cause local climates to warm and threaten tropical forest integrity and biodiversity. These externalities of the palm oil production process comprise a major threat to tropical forest ecosystems worldwide. Externalities as ecosystem threats are represented by: (A) monoproduction and industrial monocropping (photo credit: GRAIN); (B) large-scale wildfires as a result of industrial plantations (photo credit: Wahyudi, Agence France-Presse); (C) displacement by logging or fires, resource partitioning, and character displacement (photo credit: Paulina L. Ela, Borneo Orangutan Survival Foundation); and (D) edge effects and habitat fragmentation (photo credit: Willy Kurniawan, Reuters).

\subsection{Calculating the Costs}

We estimate that nearly 150 million acres of land were lost to the global palm oil industry from wildfires, deforestation, and forest and peatland transfiguration over the last decade and a half, based on data provided by Gaveau et al. [37], Ichikawa [43], and Fitzherbert et al. [44] (Figure 2). Auxiliary data on contracted farmers with strong ties to public bureaucracies and industrial plantations show that farmers with elite political and corporate relationships are significantly more inclined to convert marginal land and engage in high-risk land clearing than all other farmer groups combined $[45,46]$. Our estimate considers these risk-tolerant activities and all forms and types of land lost due to the multi-transitive influence of palm plantations on social and ecological change.

We aggregated forestry, fire, and land cover data from datacenters at the World Resource Institute, Center for International Forestry, and The World Bank. Our databank uses figures on exporters of oil to determine the rate of forest and land loss to palm oil production by country. We reviewed publications from local and national news sources, as well as federal and legal documents from major oil-producing nations, to determine the volume of converted forested and nonforested wetland, peatland, and "marginal" land 
for palm oil use [47]. These news sources provided a crucial account of underreported land lost, related to wildfires associated with socioenvironmental conflict on or near palm oil activity, allowing us to unearth new sources of externality data. Aerial estimates of land illegally logged for oil production, and land disagreements that led to small and large wildfires, were additionally used to determine the transitive relation between palm oil estates and multi-participant deforestation events $[48,49]$.

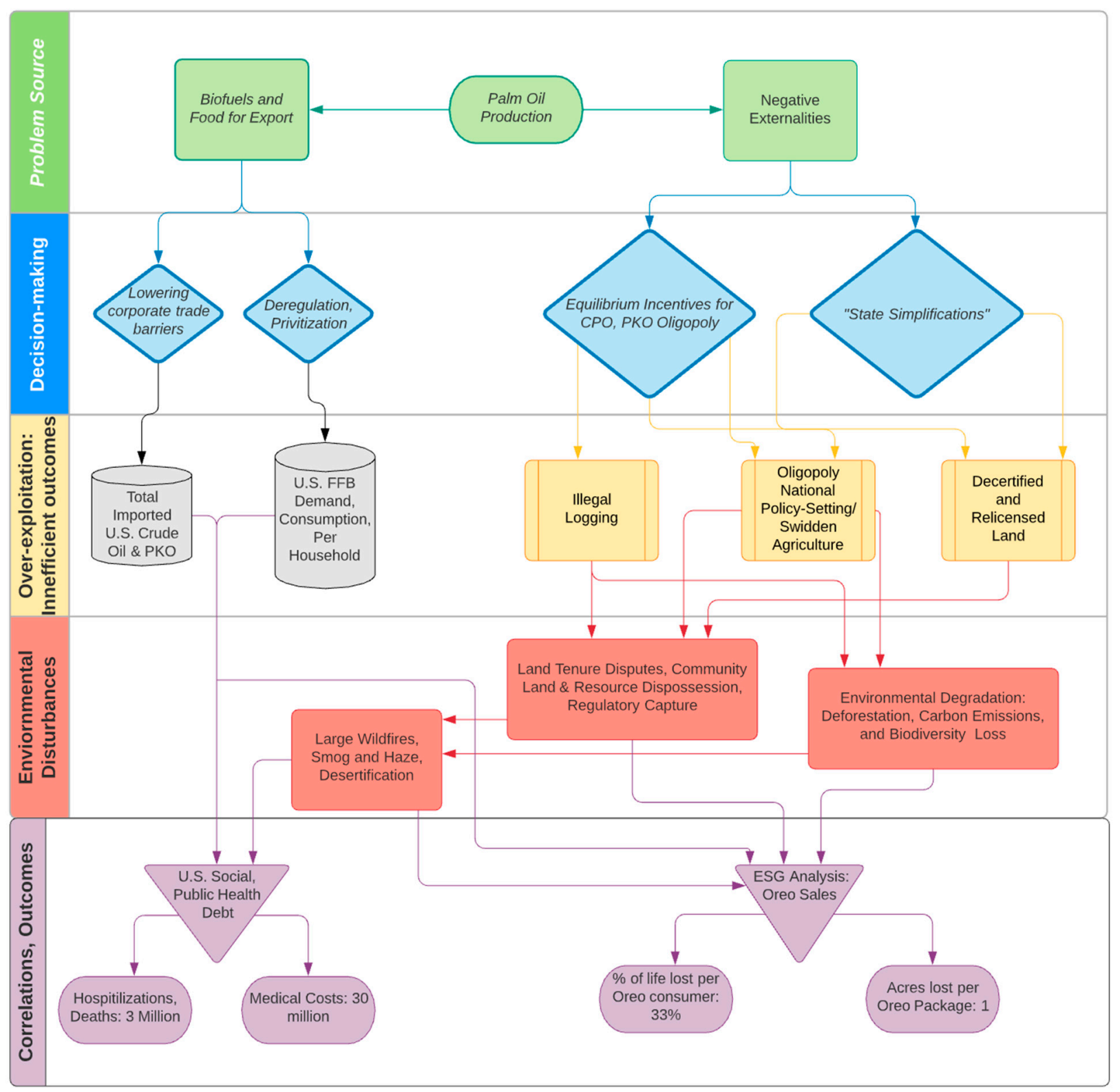

Figure 2. Relational Diagram Between Global Consumers and Palm Oil Externalities. Negative externality costs of production and consumption of palm oil diffuse rapidly as the intermediate good travels across national borders and dissipates into final goods, like snacks, detergents, and toothpaste. The perverse consequences of neoliberal, market-oriented reform policies, correlated with data on environmental disturbances and global food trade reports on Indonesia's policyand decision-making outcomes, have explicit political, social, and ecological dangers. Here, we disentangle the social and individual responsibility in consuming palm oil sourced goods, famous for instigating ecological degradation, social conflict, and economic inequality, to demonstrate the global consumption impact on the health and livelihood of disadvantaged communities across the tropics. 
These aerial estimates of palm oil-induced land-cover conversion demonstrate that industrial plantations amplify habitat fragmentation by failing to apply gradual edge vegetation measures to mitigate edge effects of forest fragmentation $[49,50]$. They also show how plantations deplete soil and above-ground carbon stocks by militarizing underage laborers to perform high-impact logging and industrial clearing on both primary and secondary forests $[15,48,51]$. Our analysis therefore considers land accumulated by plantations for the current and future expansion of crop development, land destruction from wildfires as a result of socioenvironmental conflict, and land illegally logged or converted into palm oil plantations-determining an aggregate number of total hectares lost for demonstrating how resource-rich land is captured, concealed, and withheld from public knowledge and ecological restoration efforts. It also upholds the use of polycentric governance management systems in mitigating adverse impacts on potential regrowth events and tropical forest biome security, both as a precursor to sustainable development and as a solution to maladaptive forestry policies.

It is not just a lack of consumer awareness of the environmental risks and damages that stem from purchasing palm-oil rich products that drives global demand. Transnational corporations and a widespread lack of international environmental regulations are largely to blame, yet most consumers have no idea that their household products contain ingredients responsible for widespread environmental degradation on the other side of the globe. Considering estimates of palm oil land conversion area, and that U.S. palm oil imports surpassed \$1.1 billion last year [20], we estimate that for every box of Oreos that Americans eat, an acre of forest is lost to palm oil cultivation and production (Figure 2). Put another way, each palm oil consumer in the U.S. is responsible for a loss of nearly four acres of forest land per year, an estimate that researchers and policy officials should consider in choosing to establish transparent international sustainability standards. In sum, consumer demand for the oil drives both forest habitat fragmentation and loss which further exacerbates environmental injustice among the poor and rural communities of palm oil nations.

Our valuation of land converted for biofuels and food export, tracing the record of Indonesian palm oil exports by the percentage of U.S. palm oil imports in 2015, is positively correlated with environmental insecurity and ecosystem degradation on or near palm oil monocrop plantations. We calculated the percentage of U.S. oil imports from palm oil-producing countries including Indonesia, Malaysia, Ecuador, Guatemala, Ghana, Bolivia, Columbia, and Brazil, and calculated the volume of oil detected in U.S. markets. Then, we aggregated total ecosystem disturbance reports from all U.S.-bound oil exporters by estimating total land converted to oil palm production, as well as land lost through illegal logging, "state simplification" events that led to land decertification and social uprising, and large wildfires overtly caused by swidden agriculture in regions with high concentrations of oil palm plantations. This led to a baseline rate of deforestation relative to the volume of oil supplied in U.S. markets which informed our per package and per household calculations. The same methods were used in calculating the total medical costs, casualties, and hospitalizations of human and animal life related to palm oil production.

\subsection{Threats of the Palm Oil Industry to Human Health}

Palm oil consumption worldwide, and especially in urban and rural food deserts and developing countries where food security and sovereignty are threatened, drives cardiovascular disease and mortality rates [52,53]. For example, economic-epidemiological models show that a male-targeted palm oil tax would avert the deaths of over 363,000 men from cardiovascular-related diseases and strokes in India, alone [54]. These negative health and economic burdens are especially high in poor rural communities and heavy oil-consuming countries, based on their lack of accesses to nutritious sources of caloric intake $[55,56]$. Such power relations promote the abuse of resource-rich tropical nations by economically-developed nations, whose noncommittal posturing on international sustain- 
ability standards and global public goods has long damaged the health and welfare of the world's most at-risk populations $[57,58]$.

Life cycle assessments demonstrate that the oil poses other human health hazards, as well, from land conversation via slash-and-burn agricultural practices. Land clearing for palm oil has triggered high mortality rates from smoke-induced respiratory illness and other palm oil land conversion-related noncommunicable diseases $[59,60]$. A study by Koplitz et al. (2016) [61] estimated that over 100,000 human lives were lost from direct wildfire destruction and smoke-related respiratory illnesses due to fires in Indonesia's South Sumatra Province, where $80 \%$ of palm plantations illegally use industrial logging and slash-and-burn land clearing to grow oil palms on protected lands. Such costs multiply over time as deforested lands, wildfires, and unsustainable forestry practices exponentially "desertify" the land and magnify human health hazards of palm oil production, thereby contributing to the deaths of thousands of people and the loss of billions of acres of forest in tropical nations [62-64].

\section{Collective Governance for Sustainable Palm Oil}

Some argue that sustainably sourced palm oil, or "deforestation-free" palm oil, is the best way to mitigate human and environmental harms, and reduce carbon emissions [65]. While it is true that stable, global agro-food markets are unlikely to develop without more transparent and accountable trade policies [41], interregional entanglements among environmental NGOs, local governments, and civil society are exacerbated in highly decentralized areas of the tropics, such as Indonesia, when foreign governments assume that sustainability standards face confrontational interactions between private and public agents $[66,67]$. In other words, policymakers in both the global north and south falsely assume that sustainable palm oil production is only feasible by unilateral sustainability engagements in palm oil supply chains, increasing cross-sectoral conflicts and compounding the opportunity costs associated with omitting a range of sustainability actors who would otherwise advance a sustainable policymaking and decision-making strategy in emergent nations [66,67] (Figure 3).

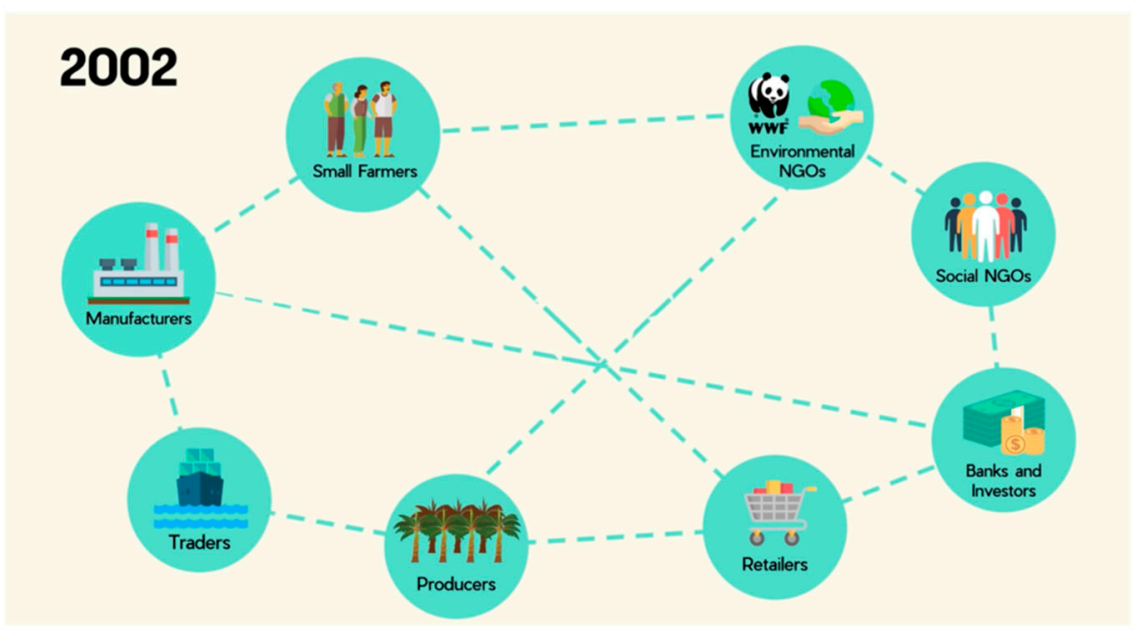

Figure 3. Multistakeholder Governance Initiatives, Roundtable on Sustainable Palm Oil (2020). A "common governance environment" with multilateral actors and global alliances, for improving the sustainable production and trade of palm oil product, has existed since 2002.

Given the current trend in increasing sustainability and transparency in global supply chains, we suggest that sustainability policy reforms are feasible and have the potential to promote 21 st century U.S. international sustainability standards. Transnational corporations (TNCs) have the capacity to accelerate large-scale systemic change and facilitate sustainability transformations in corporate biosphere stewardship [68] goal setting and, in the face of global economic development during the Anthropocene, they assert a major- 
ity role in determining the inertia and robustness of global corporate sustainability and transparency ambitions [68,69].

TNCs in the palm oil sector, where five corporations account for 90\% of globally-traded oil product, suffer from a misalignment of sustainable goals and therefore face barriers in achieving radical global transparency objectives [70,71]. These TNCs lack a credible commitment to pursue sustainable development and uphold biosphere stewardship in tropical nations where oil palm operations mainly occur, given that the weak governances systems and corrupt state-centric and decentralized governance institutions often pander to the five major oil palm TNCs [64,72]. As companies consider eco-risks, engage in ecohedging, and manage their eco-efficiency more now than in years past, today, governments have an opportunity to achieve sustainability objectives by improving trade policies using supply chain sustainability data, focusing on human rights, and including actors and agents with the contextual knowledge to solve local problems [72-74]. Streamlining sustainable trade goals and revealing the transnational corporate impact on tropical socioecological systems require a new, sociopolitical and eco-transformational solution, developed by collaborative sustainability goals and 21st century technologies (Figure 4).

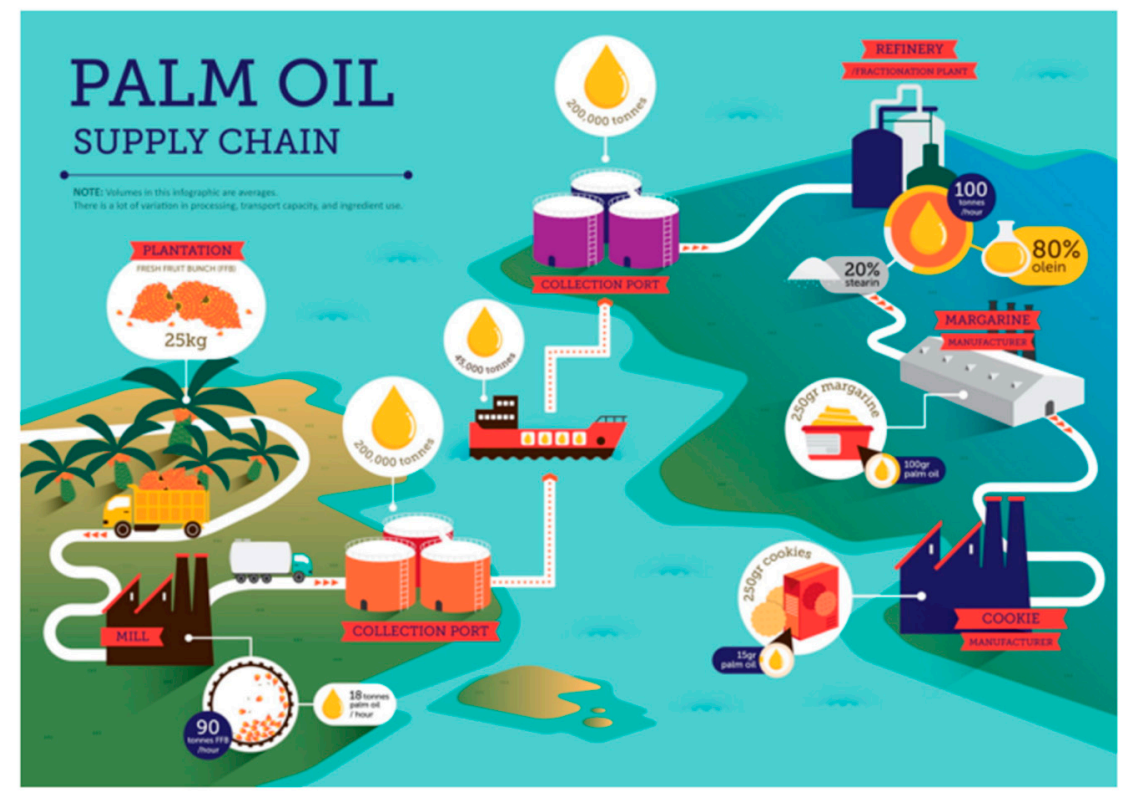

Figure 4. Supply and Distribution, Roundtable on Sustainable Palm Oil (2020). Third-party certification schemes, such as RSPO certification and ISEAL global member programs, are a step in the right direction in improving the sustainable management of palm oil. These schemes ensure interconnectedness of stakeholders and legitimize local supply chain relations in sourcing, milling, and refining palm oil derivatives.

Polycentric governance achieves collective action decision-making and componentlevel redundancy by improving the connectivity, learning, and interconnectedness across a range of actors and scales within a given policy sphere or spatiotemporal landscape [64,75]. Contrary to game theoretical predictions, these systems of well-connected governance, in which multiple governing bodies interact and overcome issues within a specific policy arena and geography, solve the issue of common-pool resource overexploitation by improving communication between a range of actors and facilitating an interdependent system of relations [76,77]. For a given socioecological setting, especially one with highly decentralized and fragmented systems of local and jurisdictional governance, polycentric governance may overcome the norms and standards assumed in competitive rivalries, normative appropriation, and provision problem outcomes [78,79]. A step in the right direction for improving multi-stakeholder accountability in the palm oil industry, for example, is evidenced by collective forestry certification programs, such as the Roundtable on 
Sustainable Palm Oil's (RSPO's) third-party grower-forest certification program, which has led to the protection of over 19\% of forest land used in the global production of palm oil [80]. While RSPO's methods are an imperfect model for sustainable palm oil production, they do yield sizeable results for reducing deforestation and limiting unsustainable production in the global palm oil industry.

Common-pool resource sustainability and climate governance in emergent tropical nations require a solution to issues of rivalry, nonexcludability, and effective boundarysetting without central coordination resources [81]. Polycentricity in government typically overcomes the common-pool overharvest issue across varying scales of centralization by improving institutional arrangements, such as in local and national governments, NGOs, and IGOs that operate in several spatial or temporal scales [79]. However, atypically, the use of indirect and nonhierarchical polycentric governance offers unique common-pool resource and climate strategy alternatives in tropical resource governance [82]. Such a nonhierarchical organization of governmental and nongovernmental units may reflect a more cohesive, adaptive, and resilient trade-sustainability standard, given that a new paradigm of cross-sector and cross-functional agreements focuses on redundant policing of resources, streamlined workflow, and organizational unity via 21st century high-tech adaptations (Figure 5).
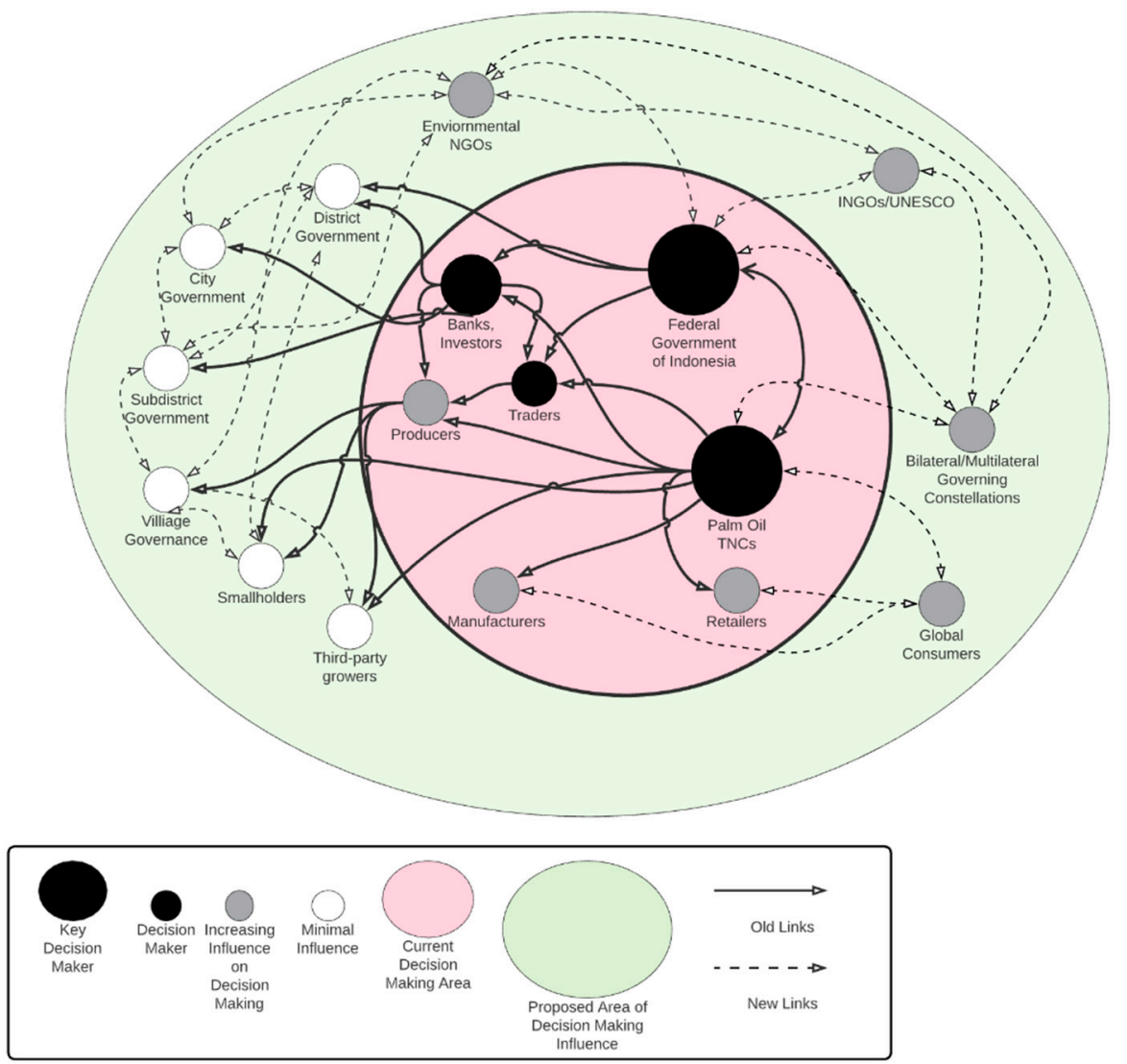

Figure 5. Non-hierarchical Polycentric Governance. Adapted from "Evolving polycentric governance of the Great Barrier Reef," 2017, T. Morrison. Many conventional systems of environmental governance are unable to cope with novel forms of social and environmental change. Polycentric governance systems occasionally struggle with adapting to the affect, speed, and depth of such multi-transitive changes. Our synthesis of a non-hierarchical polycentric system ensures inclusivity, transparency, accountability and legitimacy across all actors in the supply chain, implanting a series of micro-level transformational "nodes" for boosting response diversity in and across global actor networks. 
Our fusion of a nonhierarchical polycentric model with micro-transformational links, developed to solve the key challenges with earlier polycentric governance models that boost effectiveness but escalate transaction costs $[83,84]$, is capable of creating managerial overlap across actors, scales, and mechanisms in the palm oil supply and value chains. By coevolving the relations between small- and medium-scale actors, global consumers, and key decision-makers, this model uses micro-transformational nodes to boost the current adaptive governance capacity of the palm oil complex. In an age when nonconventional actors occupy informal positions of political leadership, such as transnational commoditytrading companies such as Wilmar Incorporated and Louis Dreyfus Company, or financiers of palm oil such as Maybank, the critical component in improving collective governance in emerging countries is a reliable method for measuring and comparing resource-based management initiatives and the realities of tropical ecosystem performance [41].

In the field of monetary and behavioral economics, the best-known solution to timeinconsistency problems in central banking involves the creation of an independent central bank, such that the bank solves time-inconsistency problems with the credibility and decision-making capacity to make unbiased decisions in favor of, or against, a given monetary policy solution. This independent monetary system thereby combats the tendency of politicians and bureaucracies to break their commitment to future payoffs (e.g., payoffs that are in the long term) in the pursuit of short-run payoffs (e.g., payoffs that are closer to the present time). Central bank independency is ultimately a mechanism for protecting a national economy from the undue influence of short-term political triage and decision-making unpredictability-especially in multiplayer systems where more than two, $n>2$, actors are given the ability to veto unfavorable activities [85] — as well as preserving the bank's credible commitment to pursue an unbiased system of macroeconomic output, stability, and growth.

This ability to solve present bias-protecting the long-run outcome of national economies from the political or economic incentive to break their commitment to the future goal by choosing to pursue the present payoff-is a notable success of modern monetary policy. Yet, this time-consistency dynamic is equally vital in identifying and overcoming issues related to Indonesian forestry policies, forestry economics, and natural resource governance. Our nonhierarchical polycentric model aims to achieve this tenant of legitimate and credible oversight, measuring and comparing resource-based management initiatives to de facto tropical ecosystem performance, such that governance over the palm oil industry is transformed by hyperlocal sources of informational accountability, transparency, and managerial overlap.

Indonesia's REDD+ program, for example, is a case for which our model presents a viable improvement. As Li (2016) points out, the major drawback of forestry governance systems, similar to that of REDD+, is that they typically result in either positive transformational change or, on the contrary, become another case of "projectification" [86]. "Projectification" is the process by which a government agent, organization, or institution is more concerned with operational efficiency and innovation of multi-agent "projects", rather than focused on embedding processes of network organization for achieving legitimate and purposeful outcomes. Such is the way in which data, knowledge, and information on multi-agent projects ultimately become inaccessible to newly-formed groups, agencies, and international organizations charged with the task of facilitating transformative change. In other words, "projectification" is the process by which crucial information is lost in translation, transition, and transference- thereby creating a model of "project" governance that has no long-term memory, as well as one that fails to achieve a precise definition, credible commitment to biosphere stewardship, or significant output.

Therefore, the lack of a resilient system of information storage, produced by constant successions of organizational adjustment in attempting to achieve a higher level of "efficiency" or "innovation", is one such reason why REDD+ programs failed to achieve policy transparency and accountability [87]. Yet, the unintended consequences of REDD+, as a series of "project governance" $[88,89]$ schemes and ideas for improving forestry conditions 
in the political, social, or environmental domain, is that its failure led to "[the evolution of a consolidating social forestry network] driven by the improved exchange and available information" [87]. In fact, this outcome was largely motivated by public demand for a more resilient system of data and information accountability. While REDD+ in Indonesia attempted to install a superior mode of environmental governance, the lack of accountable information systems at the local level ultimately failed to establish a credible commitment to reduce deforestation related to palm oil production at the regional and federal level-enabling slash-and-burn agriculture, unequally-distributed power relations, the exploitation of informal sector labor, and a coercive federal government that refuses to relinquish any measure of supervisory control.

The question of "how a nonhierarchical polycentric model is able to deliver on its promise in coordinating, adapting, and transforming environmental governance in Indonesia" is answered by its ability to generate new surpluses of transparency, facilitate social networks that reinforce time-consistent outcomes in forestry policy (similar to an independent central bank), and build better social forestry networks. Polycentric governance entails the data collection and distribution of local population reports on deforestation and illegal logging, embedded in a multilayered program of managerial reporting, insofar as it counterbalances the underreporting of environmental perturbations at either the local, city, subdistrict, or district level. It is thus a system for creating the means by which new social actors may expose the use of illegal palm oil licenses in primary forests or peatlands, as well as a decentralized public information network, designed for new power relations to emerge between local and federal institutions, where socially and spatially equitable processes are born.

An information network of this type would apply technological adaptations in palm oil licensing to collect decentralized data on "land grabs" or "illegal forestry". This provides an open-source record of areas and intervals in which the production and trade of illegal Fresh Fruit Bunches (FFB), and all illegal FFB derivatives such as Palm Kernel Oil (PKO) and Crude Palm Oil (CPO), is most likely to occur-allowing a range of actors to provide redundancy checks in overseeing the sustainable and legal production of palm oil. A blockchain technology model, similar to the distributive model at AgriChain, presents a way to boost the integration of multi-stakeholder accountability through the application of technology for accountability in agriculture [90]. This technological licensing arrangement, validated by a crypto ledger network, is a system of information supply and exchange predicated on reducing time-inconsistency problems in agriculture. It also reduces transaction and information transportation costs at lightning speeds, wielding a dynamic improvement to social forestry policies at national and international scales. These processes of global social forestry may help to identify a network of actors who perpetuate the drivers to deforestation, inform the decision-making of environmental NGOs or INGOs, and improve the credibility of long-term commitments to reduce GHG emissions and deforestation, as well as protect and preserve biodiversity.

Ultimately, the coexistence of multiple centers of decision-making on palm oil sustainability, whereby a coevolutionary and complementary system of trade and exchange sustainability is unified and implemented across stratified and decentralized regions of Southeast Asia, facilitates multi-stakeholder and cross sector alliances, transnational and trans-sectoral regime communication, and public and private sphere interaction [91-93]. Critically, nonhierarchical polycentric governance over common-pool resources in emergent tropical nations has the potential to increase the redundancy of policing and inspire response diversity $[94,95]$. While the evolution of sustainable governance depends on polycentric rules and maneuvers for shared-resource sustainability and compliance in tropical nodes, a real-world solution to oil palm-related disturbance and change will require a credible commitment to micro-transformations towards sustainable, long-term societal development, in governing and nongoverning factions. 


\section{Governmental Transformations for Sustainable Palm Oil Trade}

The ideological debate over global sustainable governance and transnational biosphere stewardship covers the political-ecological instability associated with decentralization, globalization, market-based instruments, and cross-scale governance [96]. This debate is renewed in discussions of governmental transformations associated with, and in response to, climate change and unsustainable human resource-use trajectories [97,98]. Promoting a more sustainable international food trade and global sustainability standard will require transformations in agricultural sustainability practices and a new paradigm of environmental data transparency, in which governments provide open-source data on cross-border agro-commodity sustainability at the product level, aiming for a positive quantum leap in sustainable development at the system level $[88,99]$.

Macro-level transformations of this sort require the optimization and unification of micro-level transformations. Micro-level transformations are, essentially, small-scale adjustments and transitions from conventional to unconventional standards, roles, and expectations, such as a strong governmental focus on open-source data transparency in agricultural and consumer imports to improve food trade sustainability at the system level $[100,101]$. Such a transformation would inform a set of international laws and customs while encouraging a range of societal, governmental, and nongovernmental actors to uphold a more accountable and transparent system of global palm oil trade.

To promote positive transformative policies for global trade sustainability, trade laws should integrate more transparent systems of environmental resources management and offer environmental NGOs an incentive to engage in the decision-making process on sustainable development, but they should also facilitate an open-source system of sustainability data on cross-border trade [30,102]. These solutions would require incorporating ingredient-level sustainability analyses and oil palm traceability systems in applications of data-driven sustainability, such as HowGood's Formulation Impact Tool or RSPO's PalmTrace $[41,103]$. They also would consider life cycle assessment (LCA) scenarios and emission trading schemes (ETS) in cross-sectoral and transboundary trade and exchange [101].

Such actions would inform consumers, mitigate palm-oil-associated environmental degradation, facilitate industry awareness with an accountable system of sustainable competition, and encourage the development of more sustainable land-use and resource management models in multilateral alliances between well-developed and emerging nations. This mechanism of governance yields a greater potential for U.S. trade law to measure the pace of governmental decision-making in food systems, slow the acceleration of unsustainable global capitalist agendas, preserve the human and labor rights of indigenous and poor rural populations, and attest to a reliable index of global food supply chain sustainability $[64,72,104]$.

Nations at the center of transformative sustainable governance have recently tried to uphold their global food supply chain responsibility by adopting top-down transformations towards sustainability $[88,105]$. For example, the European Union recently adopted a highly controversial ban on palm oil imports in biofuels, over concerns that oil production contributes to deforestation, global carbon emissions, and climate change [13]. This ban of palm oil in biofuels sets the tone for adopting a new paradigm of standards for international sustainability laws, as one of the premier civilization-scale transformations towards sustainability of the 21st century. However, a global civilization-scale ban on a food product for its unsustainable characteristics would likely have an even larger ripple effect on the macro food supply chain, instigating a decoupling of trade relations and coordination opportunities between emergent and economically-developed nations $[20,106]$.

A ban on goods for their eco-risks reduces the demand for unsustainable goods, yet it does little to facilitate a more transparent and accountable global supply chain that enforces and delineates the role of the state, market, and stakeholders in a sustainable system of food exchange $[107,108]$. Transformations toward sustainable governmental mechanisms may exist widely in different themes or topics, and to varying degrees, but the onus of sustainable governance should always focus on improving long-term societal 
development $[20,68,109]$. While narratives of sustainability in the EU's ban on palm oil suggest a more responsible and sustainable governance over its food supply chain, it does little to facilitate a sustainable transformation for the EU or in palm oil-producing nations.

Transformational governance requires that a government creates the suitable conditions for transformative changes, whether as micro-transformational or macro-transformational changes, to achieve long-term societal development $[64,88]$. Similar transformations in food and agricultural sustainability, such as the U.S. FDA's decision to inform consumer-level purchasing decisions by passing regulatory labeling requirements on all vegetable oils and vegetable oil blends, demonstrate this micro-transformational potential at the consumer level [13].

The state is responsible for facilitating food import standards, but individual consumers also have a role to play by refusing to purchase palm oil products. Micro-transformational policies have the potential to drastically increase consumer awareness and purchasing decisions over palm oil products, if such changes are combined with data on health studies and the negative externalities of unsustainable palm oil cultivation and consumption [20], by improving the awareness, education, and knowledge of sustainability trade data. The U.S. government should ultimately demand global supply chain transparency through improved commodity supply chain interventions and adopt policies that facilitate longterm societal development [110,111].

Another important step in micro-transformational governance would be to mandate that all importers of oil, certified by the Roundtable on Sustainable Palm Oil (RSPO), adhere to strict labor and environmental justice regulations in their labeling and consumer-facing information regulations $[112,113]$. This would inform a consumer about the health risks of oil overconsumption and remind them, through certification labeling, to observe their impact on oil production. Economically well-developed nations should therefore incorporate open-source trade data to inform consumers and remind policymakers of international supply chain sustainability $[114,115]$. However, unlike the European Union, they should open the floodgates to transparency and accountability in their trading systems, working with institutional, nongovernmental, and local actors to promote environmental conservation in emergent nations, rather than assuming unilateral action achieves sustainable development goals [116].

Such actions could dramatically ameliorate the negative impacts of the palm oil industry on human and nonhuman lives, alike-preserving human livelihoods, local communities, tropical forest ecosystems, and charismatic, endangered wildlife species including orangutans, Sumatran tigers, pygmy elephants, and Sumatran rhinos [44,117,118]. Global sustainability standards can encourage rainforest conversion efforts with shared sustainability trade data, reducing habitat loss and supporting the new age eco-business model, rather than corroborate unsubstantiated forestry assessments by weak or politicallyfractured government regimes $[58,119]$.

\section{Conclusions}

Global food-trade routes over the last several centuries were primarily used for commercial food exchange, but they also facilitated an evolving international discourse, helping shape and direct the immersion of cultural and community experience since the Iron Age and Roman Empire [20,120]. In what economists call a "high food drain", in which most of a farmer population is constrained by the cultivation of unsustainable or inefficient agricultural crops, the palm oil industry combines sociocultural identities and economic activities with oil production traditions. Meanwhile, the comparative advantage of, and hyper-demand for, the oil crop incentivizes vague or opaque modes of communication and circumspect goal-setting strategies among various global actors. As the militant industrialization of tropical nature occurs illegally, well-developed economies in the global north encourage the commodification of common-pool resources in emergent nations.

A global food trade system supported by micro-transformational sustainability and nonhierarchical polycentric governance offers long-term universal development in and 
across global supply chains. At its center, a new global trade system should encourage sustainable transformations, act as a constellation of decision-making nodes or centers, and polycentrically innovate solutions to socioecological system disturbances with diverse responses. As such, it may then enforce and delineate the role of the state, market, and stakeholders in a sustainable system of food exchange, triggering a coevolution of "green" market growth and impact, as well as empirically substantiating bilateral or multilateral claims to improve the health and welfare of nations in the global south. While palm oil is a single commodity with unsustainable and unregulated characteristics, evidence of the negative externalities of production and unmet sustainability goals represent the damage to tropical ecosystem integrity and emergent nation livelihoods from an opaque and unsustainable global food-trade system.

Author Contributions: G.B.S. compiled the data and was responsible for the original draft preparation. H.M.P. wrote the paper with G.B.S. and performed reviewing and editing to the writing. All authors have read and agreed to the published version of the manuscript.

Funding: This research was funded by Wesleyan University's Robert Schumann Institute of the College of the Environment and the Ronald E. McNair Post Baccalaureate program.

Data Availability Statement: Publicly available datasets were analyzed in this study. This data can be found here: Global Forest Watch (https:/ / www.globalforestwatch.org/, accessed on 3 November 2020); Mondelez international (https:/ / eu.mondelezinternational.com/, accessed on 3 November 2020); Forests and Deforestation (https:/ / ourworldindata.org/forests-and-deforestation, accessed on 3 November 2020); Index Mundi (https:/ / www.indexmundi.com/agriculture/?commodity=palmoil\&graph=exports, accessed on 3 November 2020); OEC (https:/ / oec.world/en/profile/hs92/palmoil?redirect=true, accessed on 3 November 2020).

Acknowledgments: We thank Cheryl Ong of RSPO for the helpful insights, as well as the following organizations/persons for their instrumental photographs: GRAIN, Wahyudi, Agence France-Presse, Willy Kurniawan, Reuters, and Paulina L. Ela, Borneo Orangutan Survival Foundation.

Conflicts of Interest: The funders had no role in the design of the study; in the collection, analyses, or interpretation of data; in the writing of the manuscript; or in the decision to publish the results.

\section{References}

1. Sundram, K.; Sambanthamurthi, R.; Tan, Y.-A. Palm fruit chemistry and nutrition. Asia Pac. J. Clin. Nutr. 2003, 12, 355-362.

2. Jackson, T.; Crawford, J.; Traeholt, C.; Sanders, T. Learning to love the world's most hated crop. J. Oil Palm Res. 2019, 31, 331-347.

3. Keng, P.; Basri, M.; Zakaria, M.; Rahman, M.A.; Ariff, A.; Rahman, R.A.; Salleh, A. Newly synthesized palm esters for cosmetics industry. Ind. Crops Prod. 2009, 29, 37-44. [CrossRef]

4. Aunger, R.; Greenland, K.; Ploubidis, G.; Schmidt, W.; Oxford, J.; Curtis, V. The Determinants of Reported Personal and Household Hygiene Behaviour: A Multi-Country Study. PLoS ONE 2016, 11, e0159551. [CrossRef] [PubMed]

5. Huang, Z.-R.; Lin, Y.-K.; Fang, J.-Y. Biological and Pharmacological Activities of Squalene and Related Compounds: Potential Uses in Cosmetic Dermatology. Molecules 2009, 14, 540-554. [CrossRef] [PubMed]

6. Ionta, F.Q.; De Alencar, C.R.B.; Dos Santos, N.M.; Bergantin, B.T.P.; Val, P.P.; Honório, H.M.; De Oliveira, T.M.; Rios, D. Effect of palm oil alone or associated to stannous solution on enamel erosive-abrasive wear: A randomized in situ/ex vivo study. Arch. Oral Biol. 2018, 95, 68-73. [CrossRef] [PubMed]

7. Padzil, F.N.M.; Lee, S.H.; Ainun, Z.M.A.; Lee, C.H.; Abdullah, L.C. Potential of Oil Palm Empty Fruit Bunch Resources in Nanocellulose Hydrogel Production for Versatile Applications: A Review. Materials 2020, 13, 1245. [CrossRef] [PubMed]

8. Kanlayavattanakul, M.; Lourith, N. Volatile profile and sensory property of Gardenia jasminoides aroma extracts. J. Cosmet. Sci. 2016, 66, 371-377.

9. Yusibani, E.; Woodfield, P.L.; Ardiah, L.; Surbakti, M.S.; Rahmi, R. Viscosity Measurement of Blended Patchouli Oil at Atmospheric Pressure and Room Temperature. J. Eng. Technol. Sci. 2019, 51, 683. [CrossRef]

10. Behr, A.; Westfechtel, A.; Gomes, J.P. Catalytic Processes for the Technical Use of Natural Fats and Oils. Chem. Eng. Technol. 2008, 31, 700-714. [CrossRef]

11. Do, L.D.; Attaphong, C.; Scamehorn, J.F.; Sabatini, D.A. Detergency of vegetable oils and semi-solid fats using micro-emulsion mixtures of anionic extended surfactants: The HLD concept and cold water applications. J. Surfactants Deterg. 2015, 18, $373-382$. [CrossRef]

12. Chaudhary, A.; Kastner, T. Land use biodiversity impacts embodied in international food trade. Glob. Environ. Chang. 2016, 38, 195-204. [CrossRef] 
13. Gardner, T.A.; Benzie, M.; Börner, J.; Dawkins, E.; Fick, S.; Garrett, R.; Godar, J.; Grimard, A.; Lake, S.; Larsen, R.K.; et al. Transparency and sustainability in global commodity supply chains. World Dev. 2019, 121, 163-177. [CrossRef] [PubMed]

14. Koh, L.P.; Wilcove, D.S. Is oil palm agriculture really destroying tropical biodiversity? Conserv. Lett. 2008, 1, 60-64. [CrossRef]

15. Gassler, B.; Spiller, A. Is it all in the MIX? Consumer preferences for segregated and mass balance certified sustainable palm oil. J. Clean. Prod. 2018, 195, 21-31. [CrossRef]

16. Koh, L.P.; Miettinen, J.; Liew, S.C.; Ghazoul, J. Remotely sensed evidence of tropical peatland conversion to oil palm. Proc. Natl. Acad. Sci. USA 2011, 108, 5127-5132. [CrossRef]

17. Basiron, Y. Palm oil production through sustainable plantations. Eur. J. Lipid Sci. Technol. 2007, 109, 289-295. [CrossRef]

18. Jamaludin, N.F.; Hashim, H.; Ab Muis, Z.; Zakaria, Z.Y.; Jusoh, M.; Yunus, A.; Murad, S.M.A. A sustainability perfor-mance assessment framework for palm oil mills. J. Clean. Prod. 2018, 174, 1679-1693. [CrossRef]

19. Gatti, R.C.; Liang, J.; Velichevskaya, A.; Zhou, M. Sustainable palm oil may not be so sustainable. Sci. Total Environ. 2019, 652, 48-51. [CrossRef] [PubMed]

20. Simoes, A.J.G.; Hidalgo, C.A. The Economic Complexity Observatory: An Analytical Tool for Understanding the Dynamics of Economic Development. In Proceedings of the Workshops at the Twenty-Fifth AAAI Conference on Artificial Intelligence, San Francisco, CA, USA, 7-11 August 2011.

21. Amin, S.I.M.; Abdul-Rahman, A.; Janor, H.; Asri, A.K.M.; Muchtar, D. Financial development and performance of palm oil industry in Malaysia. Econ. J. Emerg. Mark. 2019, 11, 135-151. [CrossRef]

22. Abdullah, I.; Mahmood, W.H.W.; Fauadi, M.H.F.M.; Ab Rahman, M.N.; Jali, F.A.A. Sustainability in Malaysian Palm Oil: A Review on Manufacturing Perspective. Pol. J. Environ. Stud. 2015, 24, 1463-1475. [CrossRef]

23. Reports, G.M. Global Palm Oil Market by Product Types (Organic and Conventional), By Forms (Crude Palm Oil, RBD Palm Oil, Palm Kernel Oil, and Fractionated Palm Oil), By End-Use (Food and Beverage, Personal Care and Cosmetics, Biofuel and Energy, Pharmaceutical, and Industrial), and Region (North America, Latin America, Europe, Asia Pacific and Middle East \& Africa). Palm Oil Market—Global Industry Analysis, Size, Share, Growth, Trends and Forecast 2020. Available online: https://www.grandviewresearch.com/industry-analysis/palm-oil-market (accessed on 22 December 2020).

24. Harahap, F.; Silveira, S.; Khatiwada, D. Land allocation to meet sectoral goals in Indonesia-An analysis of policy co-herence. Land Use Policy 2017, 61, 451-465. [CrossRef]

25. Khatun, R.; Reza, M.I.H.; Moniruzzaman, M.; Yaakob, Z. Sustainable oil palm industry: The possibilities. Renew. Sustain. Energy Rev. 2017, 76, 608-619. [CrossRef]

26. De Man, R.; German, L. Certifying the sustainability of biofuels: Promise and reality. Energy Policy 2017, 109, 871-883. [CrossRef]

27. Laurance, W.F.; Sayer, J.; Cassman, K.G. Agricultural expansion and its impacts on tropical nature. Trends Ecol. Evol. 2014, 29, 107-116. [CrossRef] [PubMed]

28. Wollenberg, E.; Campbell, B.; Dounias, E.; Gunarso, P.; Moeliono, M.; Sheil, D. Interactive land-use planning in Indone-sian rain-forest landscapes: Reconnecting plans to practice. Ecol. Soc. 2009, 14, 75. [CrossRef]

29. Dauvergne, P.; Neville, K.J. Forests, food, and fuel in the tropics: The uneven social and ecological consequences of the emerging political economy of biofuels. J. Peasant Stud. 2010, 37, 631-660. [CrossRef] [PubMed]

30. Obidzinski, K.; Andriani, R.; Komarudin, H.; Andrianto, A. Environmental and Social Impacts of Oil Palm Plantations and their Implications for Biofuel Production in Indonesia. Ecol. Soc. 2012, 17, 17. [CrossRef]

31. German, L.; Schoneveld, G.C.; Pacheco, P. The social and environmental impacts of biofuel feedstock cultivation: Evi-dence from multi-site research in the forest frontier. Ecol. Soc. 2011, 16, 24. [CrossRef]

32. Schroth, G.; D'Angelo, S.A.; Teixeira, W.G.; Haag, D.; Lieberei, R. Conversion of secondary forest into agroforestry and monoculture plantations in Amazonia: Consequences for biomass, litter and soil carbon stocks after 7 years. For. Ecol. Manag. 2002, 163, 131-150. [CrossRef]

33. Wilcove, D.S.; Koh, L.P. Addressing the threats to biodiversity from oil-palm agriculture. Biodivers. Conserv. 2010, 19, 999-1007. [CrossRef]

34. Hausmann, R.; Hidalgo, C.A.; Bustos, S.; Coscia, M.; Simoes, A. The Atlas of Economic Complexity: Mapping Paths to Prosperity; Mit Press: Cambridge, MA, USA, 2014.

35. Park, J.; Seager, T.P.; Rao, P.S.C.; Convertino, M.; Linkov, I. Integrating Risk and Resilience Approaches to Catastrophe Management in Engineering Systems. Risk Anal. 2013, 33, 356-367. [CrossRef] [PubMed]

36. Pirard, R.; Petit, H.; Baral, H. Local impacts of industrial tree plantations: An empirical analysis in Indonesia across plantation types. Land Use Policy 2017, 60, 242-253. [CrossRef]

37. Gaveau, D.L.; Locatelli, B.; Salim, M.A.; Yaen, H.; Pacheco, P.; Sheil, D. Rise and fall of forest loss and industrial planta-tions in Borneo (2000-2017). Conserv. Lett. 2019, 12, e12622. [CrossRef]

38. Ye, S.; Rogan, J.; Sangermano, F. Monitoring rubber plantation expansion using Landsat data time series and a Shapelet-based approach. ISPRS J. Photogramm. Remote Sens. 2018, 136, 134-143. [CrossRef]

39. Carlson, K.M.; Heilmayr, R.; Gibbs, H.K.; Noojipady, P.; Burns, D.N.; Morton, D.C.; Walker, N.F.; Paoli, G.D.; Kremen, C. Effect of oil palm sustainability certification on deforestation and fire in Indonesia. Proc. Natl. Acad. Sci. USA 2018, 115, 121-126. [CrossRef]

40. Putz, F.E.; Redford, K.H. The Importance of Defining 'Forest': Tropical Forest Degradation, Deforestation, Long-term Phase Shifts, and Further Transitions. Biotropica 2009, 42, 10-20. [CrossRef] 
41. Rial, D.P.; Winters, A.; de Córdoba, S.F. Non-Tariff Measures in International Trade: Classification. Data and Recent World Trends 2019. Available online: https://unctad.org/webflyer/international-classification-non-tariff-measures-2019-version (accessed on 1 October 2020).

42. Myllyntaus, T. Sustainability in danger? Slash-and-burn cultivation in nineteenth-century Finland and twenti-eth-century Southeast Asia. Enviorn. Hist. 2002, 7, 267-302. [CrossRef]

43. Ichikawa, M. Degradation and loss of forest land and land-use changes in Sarawak, East Malaysia: A study of native land use by the Iban. Ecol. Res. 2007, 22, 403-413. [CrossRef]

44. Fitzherbert, E.B.; Struebig, M.J.; Morel, A.; Danielsen, F.; Brühl, C.A.; Donald, P.F.; Phalan, B. How will oil palm expan-sion affect biodiversity? Trends Ecol. Evol. 2008, 23, 538-545. [CrossRef]

45. Schoneveld, G.C.; van der Haar, S.; Ekowati, D.; Andrianto, A.; Komarudin, H.; Okarda, B.; Jelsma, I.; Pacheco, P. Certification, good agricultural practice and smallholder heterogeneity: Differentiated pathways for resolving compliance gaps in the Indonesian oil palm sector. Glob. Environ. Chang. 2019, 57, 101933. [CrossRef]

46. Jelsma, I.; Schoneveld, G.C.; Zoomers, A.; van Westen, A.C.M. Unpacking Indonesia's independent oil palm smallholders: An actor-disaggregated approach to identi-fying environmental and social performance challenges. Land Use Policy 2017, 69, 281-297. [CrossRef]

47. Wicke, B.; Sikkema, R.; Dornburg, V.; Faaij, A. Exploring land use changes and the role of palm oil production in Indonesia and Malaysia. Land Use Policy 2011, 28, 193-206. [CrossRef]

48. Libraswulan, R.S. Palm Oil Plantations: Nowhere to Escape. Asian J. Women's Stud. 2014, 20, 122-133. [CrossRef]

49. Wuyts, K.; De Schrijver, A.; Vermeiren, F.; Verheyen, K. Gradual forest edges can mitigate edge effects on throughfall deposition if their size and shape are well considered. For. Ecol. Manag. 2009, 257, 679-687. [CrossRef]

50. Gruère, G. A Characterisation of Environmental Labelling and Information Schemes. 2013. Available online: https://www.oecd. org/env/labelling-and-information-schemes.htm (accessed on 13 November 2020).

51. Bryan, J.E.; Shearman, P.L.; Asner, G.P.; Knapp, D.E.; Aoro, G.; Lokes, B. Extreme Differences in Forest Degradation in Borneo: Comparing Practices in Sarawak, Sabah, and Brunei. PLoS ONE 2013, 8, e69679. [CrossRef] [PubMed]

52. Chen, B.K.; Seligman, B.; Farquhar, J.W.; Goldhaber-Fiebert, J.D. Multi-Country analysis of palm oil consumption and cardiovascular disease mortality for countries at different stages of economic development: 1980-1997. Glob. Health 2011, 7, 45. [CrossRef]

53. Ismail, S.R.; Maarof, S.K.; Ali, S.S.; Ali, A. Systematic review of palm oil consumption and the risk of cardiovascular disease. PLoS ONE 2018, 13, e0193533. [CrossRef] [PubMed]

54. Basu, S.; Babiarz, K.S.; Ebrahim, S.; Vellakkal, S.; Stuckler, D.; Goldhaber-Fiebert, J.D. Palm oil taxes and cardiovascular disease mortality in India: Economic-epidemiologic model. BMJ 2013, 347, f6048. [CrossRef] [PubMed]

55. Widener, M.J. Spatial access to food: Retiring the food desert metaphor. Physiol. Behav. 2018, 193, 257-260. [CrossRef]

56. Joassart-Marcelli, P.; Rossiter, J.S.; Bosco, F.J. Ethnic markets and community food security in an urban "food desert". Environ. Plan. 2017, 49, 1642-1663. [CrossRef]

57. Smit, H.H.; Meijaard, E.; Van Der Laan, C.; Mantel, S.; Budiman, A.; Verweij, P. Breaking the Link between Environmental Degradation and Oil Palm Expansion: A Method for Enabling Sustainable Oil Palm Expansion. PLoS ONE 2013, 8, e68610. [CrossRef] [PubMed]

58. Sayer, A.M.; Hsu, N.C.; Bettenhausen, C.; Jeong, M.-J.; Holben, B.N.; Zhang, J. Global and regional evaluation of over-land spectral aerosol optical depth retrievals from SeaWiFS. Atmos. Meas. Tech. 2012, 5, 1761-1778. [CrossRef]

59. Subramaniam, V.; May, C.Y.; Muhammad, H.; Hashim, Z.; Tan, Y.A.; Wei, P.C. Life cycle assessment of the production of crude palm oil (part 3). J. Oil Palm Res. 2010, 22, 895-903.

60. Kadandale, S.; Marten, R.; Smith, R. The palm oil industry and noncommunicable diseases. Bull. World Health Organ. 2018, 97, 118-128. [CrossRef] [PubMed]

61. Koplitz, S.N.; Mickley, L.J.; Marlier, M.E.; Buonocore, J.J.; Kim, P.S.; Liu, T.; Sulprizio, M.P.; DeFries, R.S.; Jacob, D.J.; Schwartz, J.; et al. Public health impacts of the severe haze in Equatorial Asia in September-October 2015: Demonstration of a new framework for informing fire management strategies to reduce downwind smoke exposure. Environ. Res. Lett. 2016, 11, 094023. [CrossRef]

62. Tan, S.T.; Hashim, H.; Rashid, A.H.A.; Lim, J.S.; Ho, W.S.; Jaafar, A.B. Economic and spatial planning for sustainable oil palm biomass resources to mitigate transboundary haze issue. Energy 2018, 146, 169-178. [CrossRef]

63. Sumiani, Y.; Sune, B.H. Feasibility study of performing an life cycle assessment on crude palm oil production in Malaysia. Int. J. Life Cycle Assess. 2007, 12, 50-58.

64. Burch, S.; Gupta, A.; Inoue, C.Y.; Kalfagianni, A.; Persson, Å.; Gerlak, A.K.; Ishii, A.; Patterson, J.; Pickering, J.; Scobie, M.; et al. New directions in earth system governance research. Earth Syst. Gov. 2019, 1, 100006. [CrossRef]

65. Meyer, C.; Dana, M. Zero deforestation zones: The case for linking deforestation-free supply chain initiatives and jurisdictional REDD+. J. Sustain. For. 2015, 34, 559-580. [CrossRef]

66. Pieck, S.K.; Moog, S.A. Competing entanglements in the struggle to save the Amazon: The shifting terrain of transna-tional civil society. Political Geogr. 2009, 28, 416-425. [CrossRef]

67. Lambin, E.F.; Thorlakson, T. Sustainability Standards: Interactions Between Private Actors, Civil Society, and Governments. Annu. Rev. Environ. Resour. 2018, 43, 369-393. [CrossRef] 
68. Folke, C.; Österblom, H.; Jouffray, J.-B.; Lambin, E.F.; Adger, W.N.; Scheffer, M.; Crona, B.I.; Nyström, M.; Levin, S.A.; Carpenter, S.R.; et al. Transnational corporations and the challenge of biosphere stewardship. Nat. Ecol. Evol. 2019, 3, 1396-1403. [CrossRef] [PubMed]

69. Schneider, A.; Hinton, J.; Collste, D.; González, T.S.; Cortes-Calderon, S.V.; Aguiar, A.P.D. Can transnational corpora-tions leverage systemic change towards a 'sustainable'future? Nat. Ecol. Evol. 2020, 4, 491-492. [CrossRef] [PubMed]

70. Kusumaningtyas, R.; Van Gelder, J. Towards Responsible and Inclusive Financing of the Palm Oil Sector; CIFOR: Jawa Barat, Indonesia, 2017; Volume 175.

71. Roche, J. Agribusiness: An International Perspective; Routledge: Abingdon, UK, 2019.

72. Haglund, L. Human Rights Pathways to Just Sustainabilities. Sustainability 2019, 11, 3255. [CrossRef]

73. Sheffi, Y. Balancing Green: When to Embrace Sustainability in a Business (and When Not to); MIT Press: Cambridge, MA, USA, 2018.

74. Rietig, K. The Power of Strategy: Environmental NGO Influence in International Climate Negotiations. Glob. Gov. 2016, 22, 269-288. [CrossRef]

75. Muldavin, J.S. Environmental degradation in Heilongjiang: Policy reform and agrarian dynamics in China's new hybrid economy. Ann. Assoc. Am. Geogr. 1997, 87, 579-613. [CrossRef]

76. Ostrom, E. Beyond Markets and States: Polycentric Governance of Complex Economic Systems. Am. Econ. Rev. 2010, 100, 641-672. [CrossRef]

77. Lubchenco, J. Entering the Century of the Environment: A New Social Contract for Science. Science 1998, 279, 491-497. [CrossRef]

78. Turner, B.L., II; Lambin, E.F.; Reenberg, A. The emergence of land change science for global environmental change and sustainability. Proc. Natl. Acad. Sci. USA 2007, 104, 20666-20671. [CrossRef]

79. Andersson, K.P.; Ostrom, E. Analyzing decentralized resource regimes from a polycentric perspective. Policy Sci. 2008, 41, 71-93. [CrossRef]

80. RSPO. A Global Standard for Sustainable Palm Oil; Roundtable on Sustainable Palm Oil: Kuala Lumpur, Malaysia, 2021.

81. Nagendra, H.; Ostrom, E. Polycentric governance of multifunctional forested landscapes. Int. J. Commons 2012, 6, 104-133. [CrossRef]

82. Abbott, K.W. The transnational regime complex for climate change. Environ. Plan. C Gov. Policy 2012, 30, 571-590. [CrossRef]

83. Sovacool, B.K. An international comparison of four polycentric approaches to climate and energy governance. Energy Policy 2011, 39, 3832-3844. [CrossRef]

84. Sovacool, B.K. Hard and soft paths for climate change adaptation. Clim. Policy 2011, 11, 1177-1183. [CrossRef]

85. Keefer, P.; Stasavage, D. The limits of delegation: Veto players, central bank independence, and the credibility of mone-tary policy. Am. Political Sci. Rev. 2003, 97, 407-423. [CrossRef]

86. Li, T.M. Governing rural Indonesia: Convergence on the project system. Crit. Policy Stud. 2015, 10, 79-94. [CrossRef]

87. Moeliono, M.; Brockhaus, M.; Gallemore, C.; Dwisatrio, B.; Maharani, C.D.; Muharrom, E.; Pham, T.T. REDD+ in Indonesia: A new mode of governance or just another project? For. Policy Econ. 2020, 121, 102316. [CrossRef]

88. Biermann, F.; Abbott, K.; Andresen, S.; Bäckstrand, K.; Bernstein, S.; Betsill, M.M.; Bulkeley, H.; Cashore, B.; Clapp, J.; Folke, C.; et al. Transforming governance and institutions for global sustainability: Key insights from the Earth System Governance Project. Curr. Opin. Environ. Sustain. 2012, 4, 51-60. [CrossRef]

89. Muller, R. Project Governance. Strat. Dir. 2011, 27. [CrossRef]

90. AgriChain Pty Ltd. AgriChain. Available online: https://agrichain.com/about-the-platform/2021 (accessed on 2 December 2020).

91. Weller, S. Beyond "global production networks": Australian fashion week's trans-sectoral synergies. Growth Chang. 2008, 39, 104-122. [CrossRef]

92. Pacheco, J.M.; Vasconcelos, V.V.; Santos, F.C. Climate change governance, cooperation and self-organization. Phys. Life Rev. 2014, 11, 573-586. [CrossRef] [PubMed]

93. Asheim, B. Differentiated knowledge bases and varieties of regional innovation systems. Innov. Eur. J. Soc. Sci. Res. 2007, 20, 223-241. [CrossRef]

94. Biggs, R.; Schlüter, M.; Biggs, D.; Bohensky, E.L.; BurnSilver, S.B.; Cundill, G.; Dakos, V.; Daw, T.M.; Evans, L.S.; Kotschy, K.; et al. Toward Principles for Enhancing the Resilience of Ecosystem Services. Annu. Rev. Environ. Resour. 2012, 37, 421-448. [CrossRef]

95. Groenleer, M.L.P. Redundancy in Multilevel Energy Governance: Why (and When) Regulatory Overlap Can Be Valuable. SSRN Electron. J. 2016. [CrossRef]

96. Ruseva, T.; Foster, M.; Arnold, G.; Siddiki, S.; York, A.; Pudney, R.; Chen, Z. Applying policy process theories to envi-ronmental governance research: Themes and new directions. Policy Stud. J. 2019, 47, S66-S95. [CrossRef]

97. Blythe, J.; Silver, J.; Evans, L.; Armitage, D.; Bennett, N.J.; Moore, M.-L.; Morrison, T.H.; Brown, K. The Dark Side of Transformation: Latent Risks in Contemporary Sustainability Discourse. Antipode 2018, 50, 1206-1223. [CrossRef]

98. Fazey, I.; Schäpke, N.; Caniglia, G.; Patterson, J.; Hultman, J.; van Mierlo, B.; Säwe, F.; Wiek, A.; Wittmayer, J.; Aldunce, P.; et al. Ten essentials for action-oriented and second order energy transitions, transformations and climate change research. Energy Res. Soc. Sci. 2018, 40, 54-70. [CrossRef]

99. Gillard, R.; Gouldson, A.; Paavola, J.; van Alstine, J. Transformational responses to climate change: Beyond a systems perspective of social change in mit-igation and adaptation. Wiley Interdiscip. Rev. Clim. Chang. 2016, 7, 251-265. [CrossRef]

100. Justino, P.; Brück, T.; Verwimp, P. A Micro-Level Perspective on the Dynamics of Conflict, Violence, and Development; Oxford Uni-versity Press: Oxford, UK, 2013. 
101. Chaabane, A.; Ramudhin, A.; Paquet, M. Design of sustainable supply chains under the emission trading scheme. Int. J. Prod. Econ. 2012, 135, 37-49. [CrossRef]

102. Paoli, G.D.; Yaap, B.; Wells, P.L.; Sileuw, A. CSR, oil palm and the RSPO: Translating boardroom philosophy into con-servation action on the ground. Trop. Conserv. Sci. 2010, 3, 438-446. [CrossRef]

103. Meijaard, E.; Morgans, C.; Abram, N.K.; Ancrenaz, M. An Impact Analysis of RSPO Certification on Borneo Forest Cover and Orangutan Populations; Pongo Alliance: Central Kalimantan, Kalimantan Tengah, Indonesia, 2017.

104. Schellnhuber, H.J.; Molina, M.; Stern, N.; Kadner, S.; Huber, V. Global Sustainability: A Nobel Cause; Cambridge University Press: Cambridge, UK, 2010.

105. Olsson, P.; Bodin, Ö.; Folke, C. Building transformative capacity for ecosystem stewardship in social-ecological systems. In Adaptive Capacity and Environmental Governance; Springer: Berlin/Heidelberg, Germany, 2010; pp. 263-285.

106. Arize, A.C.; Osang, T.; Slottje, D.J. Exchange-rate volatility and foreign trade: Evidence from thirteen LDC's. J. Bus. Econ. Stat. 2000, 18, 10-17.

107. Bureau, J.-C.; Swinnen, J. EU policies and global food security. Glob. Food Secur. 2018, 16, 106-115. [CrossRef]

108. Cashore, B. Legitimacy and the Privatization of Environmental Governance: How Non-State Market-Driven (NSMD) Governance Systems Gain Rule-Making Authority. Governance 2002, 15, 503-529. [CrossRef]

109. Gordon, L.J.; Bignet, V.; Crona, B.; Henriksson, P.J.G.; Van Holt, T.; Jonell, M.; Lindahl, T.; Troell, M.; Barthel, S.; Deutsch, L.; et al. Rewiring food systems to enhance human health and biosphere stewardship. Environ. Res. Lett. 2017, 12, 100201. [CrossRef]

110. Newton, P.; Agrawal, A.; Wollenberg, L. Enhancing the sustainability of commodity supply chains in tropical forest and agricultural landscapes. Glob. Environ. Chang. 2013, 23, 1761-1772. [CrossRef]

111. Reardon, K.; Padfield, R.; Salim, H.K. "Consumers don't see tigers dying in palm oil plantations": A cross-cultural com-parative study of UK, Malaysian and Singaporean consumer views of palm oil. Asian Geogr. 2019, 36, 117-141. [CrossRef]

112. Giam, X.; Mani, L.; Koh, L.P.; Tan, H.T. Saving Tropical Forests by Knowing What We Consume. Conserv. Lett. 2016, 9, 267-274. [CrossRef]

113. Hinkes, C.; Christoph-Schulz, I. Consumer Attitudes toward Palm Oil: Insights from Focus Group Discussions. J. Food Prod. Mark. 2019, 25, 875-895. [CrossRef]

114. OECD. Economic Outlook: Statistics and Projections (Database); OECD Economic Outlook: Paris, France, 2020 ; Volume 2020.

115. UNFSS. Voluntary Sustainability Standards (VSS). 2021. Available online: https://unfss.org/home/about-unfss/ (accessed on 2 January 2021).

116. UNEP. Environmental Governance Updates 2019, 2020. UN Enviornment Programme. 2020. Available online: https://www. unep.org/resources/report/environmental-governance-update-december-2019; https://www.unep.org/resources/report/ environmental-governance-update-october-2020 (accessed on 5 October 2020).

117. Danielsen, F.; Beukema, H.; Burgess, N.D.; Parish, F.; Brühl, C.A.; Donald, P.F.; Murdiyarso, D.; Phalan, B.; Reijnders, L.; Struebig, M.; et al. Biofuel Plantations on Forested Lands: Double Jeopardy for Biodiversity and Climate. Conserv. Biol. 2009, 23, 348-358. [CrossRef]

118. Edwards, D.P.; Larsen, T.H.; Docherty, T.D.S.; Ansell, F.A.; Hsu, W.W.; Derhé, M.A.; Hamer, K.C.; Wilcove, D.S. Degraded lands worth protecting: The biological importance of Southeast Asia's repeatedly logged forests. Proc. R. Soc. B Boil. Sci. 2010, 278, 82-90. [CrossRef] [PubMed]

119. Gerber, J.-F. Conflicts over industrial tree plantations in the South: Who, how and why? Glob. Environ. Chang. 2011, 21, 165-176. [CrossRef]

120. Standage, T. An Edible History of Humanity, 1st U.S. ed.; Walker \& Co.: New York, NY, USA, 2009. 